\title{
Biodiversity of Helminths of Sheep Breed in Vojvodina (Northern Serbia)
}

\author{
PAVLOVIĆ Ivan ${ }^{1}$, Zsolt BECSKEI ${ }^{2}$, Snežana IVANOVIĆ ${ }^{1}$, Milan P.PETROVIĆ ${ }^{3}$, Mila SAVIĆ ${ }^{2}$, Violeta CARO \\ PETROVIĆ $^{3}$, Jovan BOJKOVSKI ${ }^{2}$
}

${ }^{1}$ Scientific Veterinary Institute of Serbia, Belgrade, Serbia

${ }^{2}$ Faculty of Veterinary Medicine, Belgrade, Serbia

${ }^{3}$ Institute for Animal Husbandry, Belgrade, Serbia

* corresponding author: dripavlovic58@gmail.com

Bulletin UASVM Veterinary Medicine 74(2)/2017

Print ISSN 1843-5270; Electronic ISSN 1843-5378

doi:10.15835/buasvmcn-vm:0011

\begin{abstract}
Vojvodina is situated in the northern part of Serbia. The region is divided into: Bačka in the northwest, Banat in the east and Srem in the southwest. A small part of the Mačva region is also located in Vojvodina, in the Srem District. Vojvodina is abundant with numerous grasslands suitable for sheep grazing. The present study was conducted in 90 sheep flocks from the territory of Vojvodina in the period of March 2014 to January 2015, using into consideration the biodiversity and sesonal occurance and prevalence of isolated parasites. Fecal samples were examined by using qualitative and quantitative coprological methods. Infection we occurred at $81.22 \%$ of sheep. We found eggs of Nematodirus sp. (71.22\%), Ostertagia sp. (69.22\%), Trichostrongylus sp. (66.55\%), Haemonchus sp. (64.44\%), Chabertia ovina (60.11\%), Dictyocaulus spp. (49.00\%), Oesophagostomum sp.(36.77\%), Dicrocelium dendriticum (34.66\%), Marshallagia sp. (29.66\%), Cooperia sp. (27.88\%), Moniezia sp. (26.77\%), Bunostomum sp. (22.33\%) and Skrjabinema sp. $(13,66 \%)$.
\end{abstract}

Key words: helminths, sheep, Vojvodina, Serbia

\section{INTRODUCTION}

Vojvodina is situated in the northern part of Serbia in the southeast part of the Pannonia Plain, the plain that remained when the Pliocene Pannonia Sea dried out. Because of this, Vojvodina is rich in fertile loamy loess soil, covered with a layer of chernozem. The region is divided by the Danube and Tisa rivers into: Bačka in the northwest, Banat in the east and Srem in the southwest. A small part of the Mačva region is also located in Vojvodina, in the Srem District. Agriculture is a priority sector in Vojvodina. Traditionally, it has always been a significant part of the local economy and a generator of positive results, due to the abundance of fertile agricultural land which makes up $84 \%$ of its territory (Ognjenović, 2008). Vojvodina is rich in grasslands suitable for sheep grazing.
Pasture breeding make possible contact within eggs, larvae stages and intermediate host of parasites (Vlassoff, 1982) However, in this breeding system, it is virtually impossible to avoid infections of different types of helminths that contaminate pastures (Hubert et al.,1979). Those induce that there are no one sheep without parasites (Denev and Kostov, 1984; Vlassoff et al., 2001; Torina et al., 2004; Ardeleanu et al., 2007). This is particularly present in the semi-intensive sheep production which is a common way of breeding sheep worldwide (Cabaret et al., 2002; Agyei 2003, Bersissa et al., 2011). At the same time, parasitic infections, in addition to harmful effects of sheep, affect the reduction of their production results determine less milk yield, reduced growth and poor quality of wool (Pavlović et al. 2003, 2009). 
Parasitological examination of sheep in Vojvodina, and Serbia in total, were sporadically performed and the aim of our examination was to established species, rate of infection and seasonal dynamic of helminths at sheep flocks in Vojvodina.

\section{MATERIALS AND METHODS}

Vojvodina is situated in the northern quarter of Serbia, The region is divided into: Bačka in the northwest, Banat in the east and Srem in the southwest.Vojvodina is abundant with numerous grasslands suitable for sheep grazing.

The present study was conducted in 90 sheep flocks from the all territory of Vojvodina in the period from March 2014 to January 2015, using into consideration the biodiversity and the sesonal occurance and the prevalence of isolated gastrointestinal parasites. During study we collected fecal samples at monthly intervals during grazing season. Grazing sheep of both sexes (320 males and 580 females, for a total of 900) were randomly chosen. There were 610 adults (one-year-old and above) and 290 lambs.

Examination was performed using standard coprological technique with saturated $\mathrm{NaCl}$ solution and sedimentation (Euzeby, 1981). Eggs Per Gram count (EPG) and degree of infection we assessed by McMaster technique where EPC of 50-700 eggs we treated like low rate of infection, from 700 to 1100 like moderate and up 1100 like high (Šibalić and Cvetković, 1980). Identification of eggs of parasites were done by keys given by Euzeby (1981).

The data obtained were analyzed using Chisquare test and in all the analyses, the confidence level was held at $95 \%$.

\section{RESULTS AND DISCUSION}

Infection with helminths was occurred at $81.22 \%$ of sheep (731/900). We found eggs of next helminths genera: Nematodirus sp. (71.22\%), Ostertagia sp. (69.22\%), Trichostrongylus sp. (66.55\%), Haemonchus sp. (64.44\%), Chabertia ovina (60.11\%), Dictyocaulus spp. (49.00\%), Oesophagostomum sp. (36.77\%), Marshallagia sp. (29.66\%), Cooperia sp. (27.88\%), Bunostomum sp. (22.33\%) and Skrjabinema sp. (13,66\%). At same time we established eggs of fluke Dicrocelium dendriticum (34.66\%) and tapeworm Moniezia sp. (26.77\%). Results we represented in figure 1.

Sheep of both sexes were similarly arranged according to the number of nematode genera identified ( $p>0.05)$, whereas distribution of individuals was highly dependent of their age ( $\mathrm{p}<0.001$ ). On a total of 731 infected sheep, 242 was young and 489 adult animals.

The intensity of infection and polyparasitsm was monitored in relation to the age of sheep. It was found that in younger animals intensity of infection was lower than that of older animals. Our findings

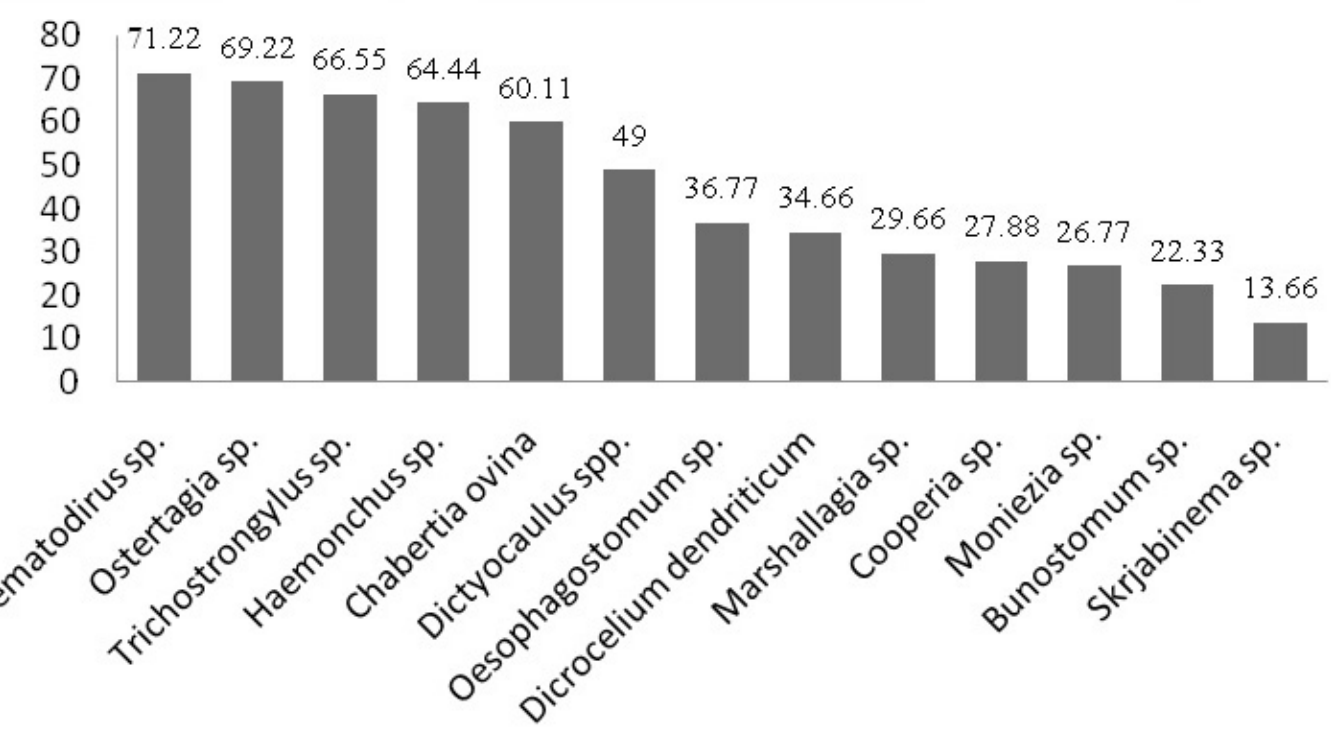

Fig. 1. Intensity of infection with ocuured helminths genera 
confirmed the results of numerous studies that reported that the higher prevalence of infection was observed in adult animals rather than in youngs. This could be the result of longer exposition of adult sheep to the parasite eggs and larvae during several grazing seasons. Adult animals usually were infected with more parasites species than young and presented potential source of infection and contaminant of pastures.

The climate condition had a strong influence on the dynamics of the first occurrence of established species of parasites. Vojvodina has a moderate continental climate characterized by cold winters and warm summers, with welldistributed precipitation and short transition seasons. In Vojvodina, four winds blow. The strongest wind is the "hair" that occurs due to air currents from the southern parts of Russia towards the Mediterranean Sea, it reaches the Danube valley and passes through the Djerdap Gorge. It is a cold and strong wind that can cause great damage: drains the land, and and raisers and transport live sand in Peshtar in Banat. "Severac" is a cold wind which in winter sharply wipes the plain, "South" is a warm wind, while the "Western" is the most common and brings rain or snow. Vojvodina has relatively small amounts of precipitations. They are mostly on the Fruska Gora (more than 750 $\mathrm{mm}$ on average) and on the mountains of Vrsac, then in the western backyard (650 to $750 \mathrm{~mm}$ ). An average of 550 to $650 \mathrm{~mm}$ of water is recorded annually. The least amount of rain has in North Baja and eastern Banat. Vojvodina has a moderate continental climate: its eastern part is more closely associated with continental and western marine influences (Ognjenović, 2008).

During start of grazing season, in March, at the start of the grazing season, faeces eggs of Ostertagia $s p$. and Trichostrongylus sp. In May, were observed infection with Nematodirus sp., .Bunostomum sp., Chabertia sp. (ovina) and Dictyocaulus sp. During June we had first record of Skrjabinema sp., Dicrocelium dendriticum and Moniezia sp. In July were established eggs of Haemonchus $s p$. (contortus) and Cooperia sp. Finally, in October, before withdrawing sheep from the pasture, we showed the presence of Marshallagia sp. Similar values were obtained during the study of the effects of climatic conditions on the occurrence of parasites in other countries with developed sheep farming (Cvetković et al., 1970; Theodoropoulos et al., 2000; Torina et al., 2004; Kenyona et al., 2009).

Semi-intensive sheep production is a tradition in the Vojvodina. Some parts of Vojvodina are abundant in grasslands, especially in the Banat region, where sheep grazing is mainly semiintesive. The rational use of pastures in the period of March-October makes the sheep production sustainable with and low input in this period of the year. Inadequate pasture management contributes to raise the prevalence of nematode infection. At the beginning of our research, conducted in March, the degree of infection with gastrointestinal strongilidae was $83.33 \%$, after which he soon reached a level of $100 \%$ in the same way and moved to the end of follow-up period. The distribution of parasites of the genera Nematodirus, Ostertagia and Trichostrongylus was reached during the monitoring period almost the maximum level. Presence of lungworms and tapeworms were in direct corelation with distribution of intermediate hosts.

We have come to these conclusions during the studies of season dynamic of GI parasites in small ruminants conducted in warious areas in Serbia in the next couple of years (Jovanović et al.1991; Vujić et al., 1991; Pavlović and Knežević, 2011; Pavlović et al.,1991, 1995, 2009b, 2011, 2013, 2015). Similar values were obtained during the study of the influence of climatic conditions on the occurrence of parasites in other countries with developed sheep farming (Ilijev,1974;Hubert et al., 1979; Denev and Kostov, 1984; Georgijevski, 1984; Vlassoff et al., 2001; Cabaret et al., 2002; Agyei, 2003; Torina et al., 2004; Ardeleanu et al., 2007; Bersissa et al., 2011).

\section{CONCLUSION}

Our results suggest that infections with helminths present significant problem of sheep in Vojvodina. The infective rate of each of these parasites showed that the most of its followed the same general pattern, having a peak in the spring and an other in the autumn, separate by a trough during the hot dry summer period when the infection rate was low. At the same time, parasitic infections, in addition to harmful effects of sheep, affect the reduction of their production results less milk yield, reduced growth and poor quality of wool. Therefore, regular parasitological control 
of the herd should be carried out before discharge into pasture and during pasture and to perform regular dehelmintization of the herd.

Acknowledgements: This study was supported by the projects number BT 31053 and TR 31085 of Ministry of Education, Science and Technology Development of Republic Serbia.

\section{REFERENCE}

1. Agyei AD (2003). Epidemiological studies on gastrointestinal parasitic infections of lambs in the coastal savanna regions of Ghana. Trop. Anim. Health Prod., 35: 207-217.

2. Ardeleanu D, Pivodă C, Neacşu M and Ida A (2007). Bio-ecolgical phenomenon of poly-parasitism - actual major problem in breeding of sheep and goats, Lucr Stiin Zoot Bioteh. 40(2): 309-317.

3. Bersissa K, Tigist T, Teshale S, Reta D and Beru H (2011). Helminths of Sheep and Goats in Central Oromia (Ethiopia) During the Dry Season, J. Anim.Vet. Adv., 10 (14):1845-1849.

4. Cabaret J, Mage C and Bouilhol M (2002). Helminth intensity and diversity in organic meat sheep farms in centre of France Vet. Parasitol., 105(1): 33-47.

5. Cvetković L, Gološin R and Kosanović M (1970). Seasonal fluctuations in the trichostrongylide worm counts in the faeces of unmated ewes and ewes which lambed in different mounths of the year, Acta Vet., 21: 77-88.

6. Denev I, and Kostov R (1984). Seasonal variations in the principal helminth infections on a sheep-grazing complex. Vet Med Nauki., 21: 81-88.

7. Euzeby J (1981). Diagnostic experimental de helminthoses animals, Vol 1. ITVC, Paris.

8. Georgievski B (1989). Rasprostranjenost i dinamika nematoda digestivnog trakta ovaca u Republici Makedonija. PhD disertation, Veterinary Facultyin in Skopje, Makedonia.

9. Hubert J, Kerboeuf D and Gruner L (1979). Study of gastrointestinal strongylosis in a sheep flock on permanent pasture. I. Sheep parasitism in 1977. Ann. Res.Vet., 10:503-518.

10. Ilijev A (1974). Fauna endoparazita ovaca na području Pelagonije u SR Makedoniji, PhD disertation, Faculty of Veterinary Medicine in Belgrade, Serbia.

11. Jovanović D, Ilić G, Nešić D, Pavlović I and Valter D (1991). Parasitoses of sheep in Timok district during 1986-1989. Proceeding of $1^{\text {th }}$ Internationaln Summer Conference for Advancement of Sheep and Goat Production, 10-15.9.1991., Ohrid, Yugoslavia, 383-385.

12. Kenyona F, Sargison ND, Skuce PJ and Jackson F (2009). Sheep helminth parasitic disease in south eastern Scotland arising as a possible consequence of climate change. Vet.Parasitol., 163(4):293-297.
13. Ognjenović S (2008). Ilustrovani atlas Srbije. EvroGiunti, Beograd.

14. Pavlović I, Nešić D, Ilić G, Jovanović D and Vlater D (1991). Parasitoses of sheep in Timok district during 1990. Proceeding of $1^{\text {th }}$ International Summer Conference for Advancement of Sheep and Goat Production, 10-15.9.1991., Ohrid, Yugoslavia, 387-389.

15. Pavlović I, Kulišić Z, Nešić D and Romanić S (1995). Endoparasites of sheep and goats in Prizren district. Proceedeing of $3^{\text {rd }}$ International Conference of Sheep and Goats Production, 5-9.9.1995., Ohrid, Macedonia, 106-110.

16. Pavlović I, Jakić-Dimić D, Ivanović S, Žujović M (2003). The effect of parasitic infection on sheep body weight. Biotech.Animal Husb., 19:145-148.

17. Pavlović I., Savić B, Ivetić V, Radanović O, Žutić M, JakićDimić D and Bojkovski J (2009a). The effect of parasitic infections to production results of sheep. Proceeding of IV Balkan Conference of Animal Science BALNIMALCON 2009, Challanges of the Balkan Animal industry and the Role of science and Cooperation, 14-16.5.2009., Stara Zagora, Bulgaria, 389-391.

18. Pavlović I, Ivetić V, Savić B, Radanović O, Žutić M and Ivanović S (2009b). Želudačno-crevna strongilidoza koza i ovaca na području Beograda Zbornik naučnih radova Instituta PKB Agroekonomik, 15 (3-4):123127.

19. Pavlović I and Knežević N (2011). Nematode parasites of sheep in spread Belgrade area at measure to its contol Congress Proceeding of $19^{\text {th }}$ International Congress of Mediterranean federation of Health and Production of Ruminants, 25-28.5.2011. Belgrade, Serbia, 328-330.

20. Pavlović I, Ivanović S, Stokić-Nikolić S, Bojkovski J, Šekler M, Savić B, Zutić M (2013). Season distribution of gastroitestinal helminths of goats in south-east Serbia. Lucr.Ştii.Med.Vet.Timişoara XLVI (5): 138-143.

21. Pavlović I, Ivanović S (2015).The influence of environmental factors on the occurrence of gastrointestinal helminths of goats in Serbia. Procceding of 4th International Congress New Perspectives and Challenges of Sustainable Livestock Production, 07-09.10.2015., Belgrade, Serbia, 549-557.

22. Stear MJ, Mitchell S, Strain S, Bishop SC and Mckellar QA (2000). The influence of age on the variation among sheep in susceptibility to natural nematode infection. Vet.Parasitol., 89: 31-36.

23. Šibalić S, Cvetković Lj (1980). Osnovi dijagnosttike parazitskih bolesti domćaih životinja, OZID, Beogard

24. Theodoropoulos G, Zervas G, Kouneli A, Martinez B, Gonzales G, Petrakos J and Kostopoulos S (2000). Seasonal patterns of strongyle infections in grazing sheep under the traditional production system in the region of Trikala, Greece. Vet.Parasitol., 89(4): 327335. 
25. Torina A, Dara S, Marino AMF, Sparagano OAE, Vitale F, Reale S and Caracappa S (2004). Study of Gastrointestinal Nematodes in Sicilian Sheep and Goats. Ann.New York Academy of Sciences, Vol.1026, Impact of Ecological Changes on Tropical Animal Health and Disease Control, 187-194.
26. Vlassoff A (1982). Biology and population dynamics of the free-living stages of gastrointestinal nematodes of sheep. In: Internal parasites of sheep. Ed. A.D.Ross. Animal Industries Workshop, Lincoln College: 11-20.

27. Vujić B, Bošković V and Savin Ž (1991). Most important parasites species of sheep and goat and its eradication. Proceeding of I International Summer Conference for Advancement of Sheep and Goat Production, 1015.9.1991., Ohrid, Yugoslavia, 375-381. 